\title{
FOOD SAFETY AND SUSTAINABILITY - AN EXPLORATORY APPROACH AT THE LEVEL OF THE ROMANIAN WINE PRODUCTION GOMPANIES
}

\author{
Gheorghe Epuran $^{1 *}$, Gabriel Brătucu ${ }^{2}$, Oana Bărbulescu $^{3}$, \\ Nicoleta Andreea Neacşu ${ }^{4}$ and Anca Madar ${ }^{5}$ \\ ${ }^{122334) 5)}$ Faculty of Economic Sciences and Business Administration, \\ Transilvania University in Braşov, Romania
}

Please cite this article as:

Epuran, G., Brătucu, G., Bărbulescu, O., Neacşu, N.A. and Madar, A., 2018. Food Safety and Sustainability An Exploratory Approach at the Level of the Romanian Wine Production Companies. Amfiteatru Economic, 20(47), pp. 151-167.

\section{Article History}

Received: 30 September 2017

Revised: 28 October 2017

Accepted: 20 November 2017

\begin{abstract}
This article aims at identifying and analyzing opinions referring to the necessity, opportunity and efficiency of the implementation of the strategies and sustainable development practices in the wine industry as food safety is considered a component of sustainability. The main objective of the paper is to create a clear picture of the existing willingness of companies to adopt marketing strategies that should contribute to increasing food security by increasing the quality of wine and which should be based on the principles of sustainability. In this sense, the authors conducted some qualitative marketing research in which 15 managers from wine producing companies from Romania's wine-growing areas were interviewed.

The research highlights the relationship between responsible consumption, food safety and sustainability, and the authors believe that such an association is relevant to the economic and social context of the European Union and other parts of the world. The novelty of this research refers to the analysis of the relationship between the responsible wine consumption and sustainability, to the identification of the opinions of the wine companies managers regarding the benefits and the limits of M2M and IoT technologies, to the emphasis of the marketing strategies and techniques considered innovative in the field of viticulture, as well as to the association of the concept of food safety by wine consumption to the aspects related to education and culture.
\end{abstract}

Keywords: sustainable development, food safety, European legislation, wine quality, wine industry, marketing strategies, education, Machine to Machine, Internet of Things.

JEL classification: L15, L66, M31, Q01, Q13, Q18.

*Corresponding author, Gheorghe Epuran - epuran.gheorghe@ unitbv.ro 


\section{Introduction}

In the current European context, the strategic and operational approaches in the wine industry are significantly oriented towards sustainable development, the initiatives in this sector being found at a global level (Pomarici, 2015) in the new configuration of the international wine market. The International Vine and Wine Organization (OIV) considers in one of its resolutions that viticulture is a 'global strategy on the scale of grape production and processing systems, while incorporating the economic viability of structures and territories, producing quality products, taking into account the requirements of precision in sustainable viticulture, environmental risks, product safety, consumer health and the assessment of historical, cultural, environmental and landscape heritage issues' (Resolution OIV-VITI 422, 2011). This definition is in line with the complex concept of food safety, which occupies an important place in the European Union directives and regulations (EC no. 178/2002; EC no. 2073/2005; EC no. 853/2004; EC no. 1830/2003; EC no. 882/2004, EC no. 854/2004, EC no. 852/2004), context in which agriculture was awarded a distinct title in the primary Community legislation, namely Title III - Agriculture and Fisheries (European Commission, 2012/C 326/01) thus being conferred certain privileges which were not eliminated or restricted at the time of the amendments to the constitutive treaties.

The existence at the European level of some institutional commitments and of a legislative framework that protect the consumers' interests regarding the safety of food consumption, represents an important element for consumers' confidence in domestic products and, at the same time, a factor that influences the purchasing and consumption behavior.

In dealing with the qualitative research in this article, two public benefits expected by the Common Agricultural Policy of Europe were taken into account, namely:

- Common Agricultural Policy ensuring food security for over 500 million inhabitants of the Union;

- protecting the environment by careful use of natural resources for food production and for ensuring quality of life today and in the future.

In concordance with these aspects and with others derived from them (education, culture, traditions, customs) the general aim of this research is to create a clear picture of the willingness at company management level to adopt marketing strategies that help increase food security by increasing wine quality in the context of sustainable development, and certain specific objectives were aimed at in the research approaches which are presented in the methodology.

The content of the article is structured in accordance with the proposed purpose and objectives with a review of the relevant literature and European food safety legislation, a description of the research methodology followed by the presentation of the results and the conclusions. In the research, two marketing strategies were taken into account, which were considered essential by the authors both for the Romanian wine market as a whole and for the producers in the current European context and closely related to consumer safety: product strategy and wine strategy promotion. The choice was based on the fact that the two strategic components of the marketing mix are essential for the idea of food safety, constituting, according to the authors, the central elements for the positioning of wines on the market. 


\section{Literature review}

Wine consumption and the significance attributed to wines have been the subject of many reflections and studies throughout time. Without making an insight into history, we note that biblical writings refer to wine in close connection with the physical and spiritual state of health, the wine being given high symbolic values: joy, Holy Spirit, wisdom and truth (Orthodox Bible, 2017). People's care to obtain wine was materialized in a magic-ritual complex, and in one of the variants of Baba Dochia story, she demanded food from God, namely, bread and wine, which were essential elements of human food (Evseev, 1999). In recent literature, addressing the issue of food consumption in the context of food safety is most often done in close relation to sustainability and value creation (Gereffi, Humphrey and Sturgeon, 2005; Barnier, 2008; Blue Skies, 2012; Neven, 2015).

Taking into account these existing approaches mainly in the European space, correlated with the utility and perceived risk assessment(Baron, 2008; Plous, 1993),, the authors are of the opinion that responsible wine consumption is a matter of balance between knowledge, pleasure, respect and self-control (Vin \& Société, 2017), which means consumption in the right amount and at its fair value, which is associated with safety aspects, subjectively extrapolated by people beyond the strictly food meaning, respectively, as projected in education, culture, traditions and customs.

On this background, the specialty literature highlights a number of elements concerning the direct or indirect involvement of customers in the world of production (Dressler, 2016), the idea of food safety and sustainability lead to an increased loyalty in relation to the longterm trustworthy brands (Holebeek, 2011) and to the idea of client integration by creating and offering value (Vivek, Beaty and Morgan, 2012). The issues related to consumer responsibility and food safety are addressed in papers referring to the wine consumer behavior (Lockshin and Hall, 2003) emphasising process of customer involvement in purchasing and consuming wine as a defining element of behavior (Hollebeek, 2011; Hollebeek et al., 2007; Cohen, d'Hauteville and Sirieix, 2009; Goodman, 2009), which is closely related to education, culture, food safety, comfort, self-representation, etc.

A special impact on the relationship between wine consumption and food security is detained by the development of information and communication technologies, especially by Machine to Machine (M2M) part of the Internet of Things (IoT), which directly intervenes on both the production technologies applied by winegrowers (Thach, 2009; Bouquet, 2012; Halstead, 2013), as well as on how consumers make purchasing decisions (Atkin and Thach, 2012; Lindsey et al., 2014). Thus, M2M involves the use of network resources to achieve good communication with the research, production and processing infrastructure. With the purpose of monitoring and controlling processes, M2M communication correlates with both technical and economic issues, which represents an important step towards "smarter charging" of these services (Maric et al., 2015), contributing to a significant way to increase the quality of wines and, implicitly, to ensure consumer food security. M2M hardware and software systems virtually automate many of the processes within companies and represent the main segments of the Internet of Things (IoT).

In the context of this research, it is also important to pinpoint the way in which the literature emphasizes the relationship between wine production and food safety concerns for the consumption and the elements of education, culture and civilization existing at the consumer level, and the synergistic effects that this association generates (Santeramo, 2015; Del Chiappa, Grappi and Romani, 2016; Winkler and Nichosas, 2016; Santeramo, Seccia 
and Nardone, 2017). On this relational background, by highlighting the cultural and aesthetic valences of wine consumption, Gheorghe Csavossy, a renowned viticulture professor and researcher, considers that Wine is the gift of heaven, we don't drink it for its alcohol content, but for its aesthetic value (Csávossy, 2017), and in a relatively recent work published in Romania, the wine is considered a phenomenon of culture and spirituality (Iancu, 2013), the perenniality of culture reinforcing the idea of food safety through responsible consumption of wine in the context of sustainable development.

Given the criticism and skepticism of many authors (Lipson, 2007; Perkins and Neumayer, 2010; Cho, 2016), especially regarding the practical aspects of sustainability, we believe that in order to increase efficiency and credibility at a conceptual and operational level, a new component is mandatory - the citizen's safety - which is an explicit corollary or a "background" of the three classic pillars of sustainability, the citizen being present in a specific way in each pillar (economy, environment, society).

\section{The European regulatory framework referring to food safety and its correlation with the Romanian legislation}

In the Report of the World Commission on Environment and Development: Our Common Future (Brutland Commission, 1987), it is specified the fact that, in the context of the limitations imposed by the current technologies, by the social organization, and by the capacity of the biosphere to absorb the effects of human activity, nations can meet the needs of the present without affecting or compromising the possibility of future generations to meet their own needs.

At the European level, the main concerns over the last 20 years referring to agro-food products have resulted in regulations that mainly refer to production and communication, namely, the technological and public relations conditions, without the others (prices and distribution) being neglected. Thus, the general legislation in the field, adopted in 2002, laid the foundations of the European Union's food policy. It is about the Regulation (EC) no. $178 / 2002$, which establishes the general principles and requirements, laying down the basic principles for the quality of food for human consumption in the European Union. In the same context, as early as January 2002 the European Food Safety Authority (EFSA) has been established, whose main mission is to provide support for the scientific control and evaluation of food and feed (According to Article 22 of the Regulation (EC) no.178 2002). It is thus noticed that the sustainability aspects are taken up and analyzed at the European Union level, as the European consumers want to have access to quality and healthconscious products. The major concern of the European Union is to ensure that the food is at the same level of quality standards for all European citizens, irrespective of whether it is produced or processed within the Union or imported.

As far as the agro-food in general is concerned, the European Union, by its institutions, aims at increasing consumer confidence in agro-food products by requiring a level of quality regulated by unanimous production standards in the internal market and by requiring complete and correct consumer information tools on the content of agro-food products, on the technological processes that are used and on the data about the producer/ distributor by common and compulsory rules referring to the labeling and packaging of agro-food products, while the legislative framework is permanently upgraded and improved (Moody, Kireeva and Butucel, 2010). 
In line with the objectives of the research in this article, we emphasize the fact that, as a result of the reform of the Common Agricultural Policy (CAP), organic farming practices (Regulation (EC) no. 1305/2013) are regulated by binding normative acts since 2013, fairer systems for supporting the farmers, as well as by direct subsidies, and by increasing the importance of farmers in the food chain by the mandatory labeling of products with the indication of the place of production and the specification of the ingredients. The products are tracked throughout the food chain, with a mandatory traceability of products (Regulation (EC) no. 178/2002), thus ensuring compliance with the minimum food quality standards at the level of the Union, and the prevention and control of communicable diseases through agricultural products.

Given the development of the processing technologies and of the scientific research concerning the development of hybrid and surrogate products close to the nutritional values of traditional agro-food products, the conditions for the production and marketing of food products that are part of the fourth generation of products for human consumption (Diaconescu, 2005), namely cloned, genetically modified products and food additives were defined strictly and uniformly at the level of the European Union.

With respect to the production of wines and strong alcoholic beverages, but not only, at the European level, a study was carried out, its main objective being to identify the size and value of the geographical indication (GI), as well as the proportion of products that breach the regulations and that may affect consumers' food safety (European Union Intellectual Property Office, 2017). Besides the food safety requirements related to production, there are specific regulations for information and publicity for food products placed on the market at the European Union level (Council Directive CEE/84/450). Thus, as early as 1978, the framework for the labeling, presentation and advertising of foodstuffs was established by the Council Directive CEE/79/112, all of them being defined as 'the set of mentions, indications, production or marketing marks, images or symbols relating to foodstuff and which appears on any packaging, poster, label, ring or banderol accompanying or referring to the product', a definition that was almost identically assumed by Article 2 (2) (j) from the Regulation (EC) no. 1169/2011. By these, the fundamental right of consumers to choose healthy and necessary products is guaranteed, by the real-time and easy access to complete and real product information and depending on which they can make fully-aware purchasing decisions. According to Article 3 from the Regulation (EC) no. 1169/2011, "the provision of food information aims at ensuring a high level of protection of consumers' health and interests by offering to the end consumers a basis to make an informed choice and to safely use food, taking into consideration mostly health, economic, environmental, social and ethical considerations."

By the legislative regulations, "the Union contributes both to the protection of consumers health, safety and economic interests, and to the promotion of their right to information, education and organization in order to protect their interests" (European Commission, 2012/C 326/01). Consumer protection policy represents a strategic element of the European Union to improve the quality of life of its citizens. By asserting the primacy of consumers' legitimate needs to support and develop the consumption of products and services, on April $9^{\text {th }} 1985$, UN General Assembly Resolution adopted the resolution no. 39/248 in which "The guiding principles for consumer protection" are stated, according to which the norms of behavior of the economic operator and the rules for processing, presentation and 
assurance of the quality of products must aim to meet the needs of consumers through the products offered on the market (Resolution UN 39/248, 1985).

Taking into consideration the existing regulatory framework at the European level, in Romania Law no. 164 from June $24^{\text {th }} 2015$ of vine and wine in the system of the common organization of the wine market was passed, whose purpose is to establish the general legal framework for the operation of the wine sector as regards the production, certification of origin, marketing and control of wine products defined according to the requirements of European bodies (Law 164/2015). The Law of Vine and Wine has clear objectives which aim at the increase of the competitiveness of the wine sector by exploiting plantations in good agricultural and environmental conditions (sustainability), the protection of registered designations of origin, the geographical indications and the traditional mentions (consumer protection correlated to culture and traditions aspects), as well as the permanent adaptation of the production to the requirements of the market and of the consumer (Law 164/2015). As a result of the concern for consumer protection, the law stipulates distinctly the promotion of moderate and responsible wine consumption, as well as broadcasting information on the harmful effects of excessive wine consumption (Law 164/2015).

With regard to food promotion strategies, at the level of the European Union rules have been established to harmonize Member States' legislation on labeling, presentation and advertising norms in order to eliminate any possible obstacles to the free movement of foodstuffs and the practices of unfair competition on the market, respectively, in order to protect the interests of the European consumers, who are thus guaranteed the right to choose products fully informed (Regulation (EC) no. 1169/2011). In this context, having as main topic the consumer's protection and aiming at ensuring the free movement of safe and healthy food products within the EU internal market as well as the increase of consumer confidence in food products, the principles and the definition of food labeling, the obligations of producers referring to consumer information and the minimum mandatory specifications which have to be found on food labels were adopted in the national legislation by Romanian Government Decision no. 106/2002, as regulated by Regulation (EC) no. 1169/2011.

The presentation of these aspects represents a motivation for the authors to make qualitative research focusing on food safety, sustainability and responsible consumption, about product and communication/ promotion strategies at the level of wine companies in Romania.

\section{Research methodology}

The research conducted and presented in this article was of a qualitative nature and it aimed at identifying and analyzing the opinions of the managers of the wine producing companies in Romania regarding the food safety in the context of the implementation of the sustainable development strategies in the wine industry. The main objective of the paper is to create a clear picture of the preoccupations of wine-producing companies in Romania for the adoption of marketing strategies that should contribute to the improvement of food safety by increasing the quality of wine and that should be based on the principles of sustainability. The specific objectives pursued in the research were:

- lestablishing the extent to which the principles of sustainability and food safety lie within the strategic vision of wine producers; 
- identifying the opinions concerning the benefits and costs of implementing M2M (Machine to Machine) and IoT (Internet of Things) based production methods, by which wine producers can increase the level and idea of food security;

- establishing the extent to which the application of innovative marketing techniques and their integration into the company's overall strategies contribute to the highlighting of the food safety aspects

- identifying the managers' opinions about the association of food safety regarding the consumption of wines with the existing elements of education, culture and civilization at the level of consumers.

The qualitative research method that was chosen was the interview, and the qualitative research technique was the in-depth interview (Brătucu, G. and Brătucu, T.O., 2016), the authors wanted to know the opinions of managers in the wine companies. The method used in the research was semi-structured interviewing, and the interview guide was used as a tool. The sample included a number of 15 people, managers of the wine companies from the representative areas of Romania according to AGRO BASF Division (2017), and they fulfilled the necessary conditions to meet the purpose and objectives of the research, that is having strategic decision-making power. The participation in the interview happened on a voluntary basis, a selection questionnaire was used beforehand in which, in the beginning, the purpose and the objectives of the research were presented. After the agreement of the 15 managers, the guide for the in-depth interview was conducted.

To carry out the research, the authors thought about six wine regions in Romania, comprising 37 vineyards with a total cultivated area of 180,000 hectares of vineyards where 119 producing companies operate. The selection of the managers from the companies that operate in these regions was decided depending on the cultivated area and on the production capacity, regrouping the regions to facilitate the field movement for research, thus deciding on six regions, all the data being presented in table no.1. Regrouping regions is not done in order to influence the results, given that, through its specificity, qualitative research implies a holistic approach and does not seek to "isolate" a whole by analyzing a small number of variables.

Table no. 1 Wine growers in Romania, by regions, by size in 2016

\begin{tabular}{|c|c|c|c|c|c|c|c|c|}
\hline \multirow{3}{*}{ Wine region } & \multicolumn{6}{|c|}{ Producer category } & \multirow{3}{*}{ 疍 } & \multirow{3}{*}{ 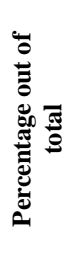 } \\
\hline & \multicolumn{3}{|c|}{ Cultivated area } & \multicolumn{3}{|c|}{ Production capacity } & & \\
\hline & $\begin{array}{c}\text { Large } \\
\text { (over } \\
200 \text { ha) }\end{array}$ & $\begin{array}{l}\text { Middle size } \\
\text { (between } 20 \\
\text { and } 200 \text { ha) }\end{array}$ & $\begin{array}{c}\text { Small } \\
\text { (between } 5 \\
\text { and } 19 \text { ha) }\end{array}$ & $\begin{array}{c}\text { Large } \\
\text { (over } \\
5000000 \\
\text { liters) }\end{array}$ & $\begin{array}{c}\text { Medium } \\
\text { (between } \\
100000 \text { and } \\
5000000 \text { liters) }\end{array}$ & $\begin{array}{c}\text { Small } \\
\text { (under } \\
100000 \\
\text { liters) }\end{array}$ & & \\
\hline Banat & 1 & 5 & 2 & 1 & 1 & 6 & 8 & 7 \\
\hline $\begin{array}{l}\text { Crișana- } \\
\text { Maramureș }\end{array}$ & 2 & 8 & 3 & 1 & 1 & 1 & 3 & 11 \\
\hline Transilvania & 1 & 6 & 1 & 1 & - & 7 & 8 & 7 \\
\hline Moldova & 6 & 10 & 1 & 9 & 3 & 5 & 7 & 14 \\
\hline Dobrogea & 4 & 9 & 2 & 3 & 4 & 8 & 5 & 13 \\
\hline Muntenia Oltenia & 8 & 40 & 10 & 15 & 24 & 19 & 8 & 49 \\
\hline Total, by categories & 22 & 78 & 19 & 30 & 33 & 56 & 19 & 100 \\
\hline $\begin{array}{l}\text { Percentage out of } \\
\text { total, by category }\end{array}$ & 18 & 66 & 16 & 25 & 28 & 47 & & $*$ \\
\hline
\end{tabular}

Source: Processed after the National Office of Vine and Wine Products, 2017 
In the research, the guided sampling was chosen by using the allowance method, which proved to be appropriate in several previous qualitative researches (Silverman, 2013; McIntyre et al., 2015).

The main considerations that were examined in establishing the sample were, on the one hand, its size and structure, aspects that are considered relevant in the literature, even if the opinions of some authors are not highly precise (Golafshani, 2003; Silverman, 2013), and on the other hand, the complex concept 'the power of information' (Malterud, Siersma and Guassora, 2016), a concept considered by the authors of this research to be the most likely to lead to the achievement of the goal and of the objectives of the research, as it covers multiple aspects that are bound together (food security, sustainability, responsible consumption, education, culture, traditions, etc.). As a qualitative research, the sample is not representative and its composition is presented in table no. 2 .

Table no. 2. Composition of the selected sample for the qualitative research

\begin{tabular}{|c|c|c|c|c|}
\hline $\begin{array}{c}\text { The } \\
\text { interviewee * }\end{array}$ & $\begin{array}{c}\text { Function within } \\
\text { the wine growing } \\
\text { company }\end{array}$ & $\begin{array}{c}\text { Name of the wine } \\
\text { producer }\end{array}$ & Producer category & $\begin{array}{c}\text { Seniority on } \\
\text { the Romanian } \\
\text { market }\end{array}$ \\
\hline Manager 1 & General manager & Amfiteatru Vitis & Small producers & 1 year \\
\hline Manager 2 & General manager & DAVINO & Middle size producers & 13 years \\
\hline Manager 3 & General manager & $\begin{array}{c}\text { Licorna } \\
\text { Winehouse }\end{array}$ & Small producers & 5 years \\
\hline Manager 4 & General manager & $\begin{array}{c}\text { Domeniile } \\
\text { Săhăteni }\end{array}$ & Middle size producers & 13 years \\
\hline Manager 5 & General manager & LACERTA & Middle size producers & 5 years \\
\hline Manager 6 & General manager & $\begin{array}{c}\text { S.E.R.V.E. } \\
\text { Ceptura }\end{array}$ & Middle size producers & 15 years \\
\hline Manager 7 & General manager & Domeniul Bogdan & Middle size producers & 5 years \\
\hline Manager 8 & General manager & Domeniile Tohani & Big producers & 26 years \\
\hline Manager 9 & General manager & Vila Vinea & Middle size producers & 10 years \\
\hline Manager 10 & General manager & Rașova & Small producers & 1 year \\
\hline Manager 11 & Chairman & Cotnari & Big producers & 26 years \\
\hline Manager 12 & General manager & Panciu & Middle size producers & 12 years \\
\hline Manager 13 & General manager & Jidvei & Big producers & 27 years \\
\hline Manager 14 & General manager & Odobești & Middle size producers & 15 years \\
\hline Manager 15 & General manager & Huși & Middle size producers & 23 years \\
\hline
\end{tabular}

* the names of the interviewed managers were not mentioned in order to preserve the confidentiality of their identity

In order to increase confidence in the research results, the authors considered, as early as the stage of the methodology selection, two concepts relevant to qualitative research: transactional validity, which involves a great interaction between the researcher and the members of the sample, and validity by transformation, which aims at bringing the sample to a size considered optimal (Creswell and Miller, 2000; Fine et al., 2000; Bradbury and Reason, 2001; Atkinson, Coffey and Delamont, 2003; Cho and Tent, 2006).

The semi-directing in-depth interview was conducted between June $15^{\text {th }}$ and July $30^{\text {th }} 2017$, based on the above-mentioned topic, at the headquarters of the companies where the selected managers operate. The answers were recorded and then stored in electronic files. Subsequently, these files were transcribed, the information being processed by the technique known as content analysis. 


\section{Results and discussions}

After transcription and centralization, the interviews were analyzed in two ways (Cătoiu, 2002):

- the vertical analysis, by the individual approach of each interview, namely the opinions of each manager, when the attention given by them to the issues included in the further topics of the interview was highlighted;

- the horizontal analysis, by the synthesis of the approach of each topic analyzed by all 15 managers.

\section{Topic no. 1. Principles of sustainability and food safety in the strategic vision of wine producers}

The interviewed subjects consider that the sustainability of the wine sector requires strategic thoughts and operational programs related to water, pesticides and other soil and fertilizer chemicals management, as well as the use of machinery and equipment that should respect biodiversity. Although all of these are known in principle, only one company partially addresses them from a strategic perspective, by having systems for pesticide management and for soil and fertilizer management implemented. In two companies, the water management procedures are implemented by a modern drip irrigation system and in three companies the cardboard used for packaging the bottles is provided by a company that uses around $80 \%$ recyclable materials for cardboard production.

In the context of sustainability, nine out of the 15 interviewed managers refer to bio certifications (organic, bio (biologic) and ecologic terms are used for international food products and refer to products obtained by certified organic production methods. The certification term recognized in Romania is Ecological Agriculture, abbreviated "ae" (Romanian Ministry of Agriculture and Rural Development, 2017), considering that they meet the necessary conditions, but the advantages obtained are small compared to the imposed limitations and exigencies, which imply high costs. The idea of an eco-product is associated with sustainability, the benefits being economic (high sales prices), social (food safety, lifestyle, self-representation) and also environmental (long-term biodiversity protection). The managers consider that, paradoxically, the costs for the bio-wine production are related to practices in the field and not to obtaining and guaranteeing a level of quality. In case of a disease or pest attack, classical treatments cannot be applied, and the grapes cannot be grafted or, if they are grafted, a poor quality wine results, which is inconsistent with the idea of food safety. Another aspect seized by all interviewed managers is the one related to the fact that wine consumers perceive the practice of bio-labeling (ae) rather as a marketing action that favors form against the contents, of the truth about wines. Consumers do not associate the idea of an eco-product with sustainability.

Topic no. 2. The benefits and costs for the implementation of M2M based production methods (Machine to Machine) and IoT (Internet of Things) by which producers can increase the level and idea of food security

The authors aimed at identifying the interviewees' opinions on the knowledge and effective use of the new technologies in the wine industry within companies, by which sustainable development, food safety and wine quality are focused on. In the context of the Fourth Industrial Revolution, the managers of wine companies accept the reality that within the EU

Vol. $20 \cdot$ No. $47 \cdot$ February 2018 
a special emphasis is placed on increasing food safety and wine quality by the use of modern technologies, while applying the specific European legislation, but they believe that the European legislation in this regard is over particular and it leads to additional implementation costs, which leads to a decrease in their competitiveness, especially in foreign markets. Even if M2M and IoT techniques are known, their use by Romanian producers that are present on the wine market at this moment is only the privilege of large companies given the high costs involved.

Thus, for four large wine growing companies there is a monitoring station for climatic parameters on the plantation, which, besides the role of monitoring, has the role of preventing, indicating in real time the risk for each of the diseases that can affect the vine. The ventilation and air conditioning system in the cellar as well as humidity in certain areas are operated and remotely controlled from devices connected to a network. In the other companies M2M and IoT are not used as technologies, the analysis of the soil chemical composition is very infrequent, once every few years, and the cellars are built in the soil to maintain a constant temperature ( $14 \mathrm{C}^{0}$ at wintertime and $17 \mathrm{C}^{0}$ in the summer).

As for wine quality, as a central element in food safety, all companies monitor it continuously, even from the grape stage. Starting from the basic elements of checking the level of sugar, acidity, very complex analyzes are made which determine each chemical component of the wines in all large companies. In a large company, besides the classical methods of analysis, an automatic analyzer, specially made for the wine industry, has been invested in and which can make 350 distinct analyzes. These aspects are in line with the theory of methods used by consumers to eliminate or at least mitigate the risk incurred before buying. (Barrena și Sanchez, 2009; Tian-Que, 2012; Marinelli ș.a., 2014; McDonald, 2016.).

Topic no. 3. The application of innovative marketing techniques and their integration in the company's overall strategies for the increase of food safety in the current European context.

In order to emphasize these aspects, besides the companies that operate exclusively on the internal market, subjects who have recently entered the international market were interviewed, generally small exporters as well as renowned exporters from those selected in the sample that operate in major export markets such as the USA and China. One of the managers said that the company he runs is not focused on volume, he does not want it to be present in neighborhood restaurants, but it is present in restaurants that are found in Top 10 restaurants in the European capitals. A larger producer said that $35 \%$ of the production is for export and that it is present in Belgium, the Netherlands, the USA, Canada, China and Japan. Another producer said that $20 \%$ of the production is for export, with wines going so far as Europe, North America, China and Japan.

Among the most popular known and implemented strategies are sommelier promotion and online presence by the web site, including an active presence in social media. Other marketing actions and techniques were: tasting, participation in international and national fairs, direct promotion by events and thematic evenings, gourmet evenings or presentations in restaurants, cooperation with associations and producers throughout the country, as well as close relations with the distributors.

In order to strengthen the idea of food safety, 11 producers consider the winery tours and virtual tours useful as the manufacturing process from the first fertilization to the finished 
product is presented. Amongst the modern marketing techniques each producer mentioned at least one of the following: the company website, blogging, WebPr, the online store. Only one manager claimed that he does not resort to traditional marketing (he does not resort to the promotion of wine by means of sommeliers, he does not organize virtual tours, the company is not present in the social media) because the company is based on the high quality of its products, and the main marketing strategy that it retorts to is based on PR elements, doubled by constant and close relations with the intermediaries (distributors, restaurants, specialized shops, etc.). Equally, the company cooperates with specialized organizations in the field (member of the Association of Premium Producers, the University of Agronomy in Bucharest as provider of teaching material), the company financially supports the organizations in the field, but it does not use them to promote its products, as it considers that a strong brand, a personal and emotional approach of Horeca customers, is the key to success.

The positioning within the corporate segment is another example of a marketing strategy, which involves the sale of personalized labeled wines for corporate parties and events. A particular way of promotion is the establishment of the Knights Club, which organizes thematic events, wine tastings, and club members benefiting from certain advantages. For one of the producers, the most important promotion strategy is the association with the Royal House of Romania, which brings along an image and trust benefit in the quality of the provided products and, consequently, the safety of consumption.

Topic no. 4. The combination of the food safety related to wine consumption and the elements of education, culture and civilization existing at the consumer level

The producers that were interviewed claim that wine should be consumed in limited quantities and that the main motivations of consumption should not lie with alcohol content, but in elements of culture, traditions and civilization, a context in which permanent education in this field is absolutely necessary. The interviewed managers correlated the consumption of wine in a cultural and educational context with events and institutions, such as: The Wine Route, as an European project existing in Romania since 2000, the International Festival of Vine and Wine which were accompanied by other local cultural projects dedicated to wine, namely, the Vine and Wine Museums in Minis, Arad County, Hârlău, Iaşi County, Murtfatlar, Constanţa County. To sum up, eight out of the 15 managers consider that food safety is not only about aspects of physical health, but also about elements that are strongly anchored in the culture and civilization of every people (Gârdan, Geangu and Roșu, 2011), which leads to their approach of the concept of sustainability, with great accuracy and relevance.

\section{Conclusions}

Food safety, their sustainability and strategic approach in the current European context are concerns whose importance differs at the level of wine-producing companies in Romania. Even if it is a priori and declaratively correlated with food security, sustainability does not have a well-defined place in the strategic vision of wine producers, as they consider that, from an economic and social point of view, the steps could be successful, but from the point of view of the strict observance of environmental regulations there are many economic, financial and social impediments, which make the production of long-term, environmentally-friendly or bio-friendly wines to remain only at the level of a desideratum.

Vol. $20 \cdot$ No. $47 \cdot$ February 2018 
The managers of wine companies know both the benefits and the costs of the implementation of M2M and IoT technologies in the context of the increase of food quality and safety, but their opinions converge to the fact that the implementation of these technologies is the privilege of the strong ones, for the other producers generating high costs which lead to the reduction of competitiveness on both the internal and export markets. As for the marketing activities focusing on food safety and sustainability, correlated with the brand image, it is noticed that at the level of the wine-producing companies a mixture of strategies and techniques is applied, whose object is both the promotion of wines and the increase of trust in consumers. The main marketing strategies and techniques involved are in the field of public relations and online marketing (WebPr, social media mix, blogging, social networking sites, etc.).

An important aspect emphasized by a great number of the interviewed managers is the relationship they establish between wine consumption, food safety and sustainability, considering that food security by wine consumption does not strictly refer to maintaining physical health. In their opinion, the main motivation of wine consumption should not be the alcohol content, as it is the case with the consumption of low-quality or counterfeit wines, but a series of aspects related to education, culture, civilization, traditions, lifestyle, etc., aspects that are found in the communication axis within the advertising messages broadcast by large companies. The authors consider that the sense and meaning of wine consumption given by the interviewed managers truly highlight the social importance of food safety and the real facet of the concept of sustainability.

The central element of novelty in this article is the addition of a distinct component at conceptual level and its explanation as a result of the qualitative research, namely the safety of the consumer considered as a corollary or "background" of the actions found at the three pillars of sustainability: economy, environment, society. Both explicitly and implicitly, the exploratory research has resulted in essential aspects of food safety in the context of sustainability, the way in which safety concerns are reflected in strategic reflections at wine producers, how new M2M/IoT technologies contribute to monitoring and controlling wine quality mitigating the perceived risk before buying and consuming, thereby giving a higher level of food safety. The research has the limits inherent to any qualitative research, the authors creating a holistic approach and a relatively subjective selection of research units. These limits can be eliminated through a future quantitative research that quantifies the resources available in each region as precisely as possible and builds the configuration of local vine and wine clusters in order to generate additional value for the consumer in the context of food safety and sustainability.

\section{References}

AGRO BASF, 2017. Ghidul principalelor regiuni viticole și podgorii din România. [online] Available at: <https://www.agro.basf.ro/agroportal/ro/ro/ stiri/stirile_agricole/ ghidul-principalelor-regiuni-viticole-si-podgorii-din-romania-311936.html> [Accessed 06.03.2017].

Atkin, T. and Thach, L., 2012. Millennial wine consumers: risk perception and information search. Wine Economics Policy, 1, pp.54-62.

Atkinson, P., Coffey, A. and Delamont, S., 2003. Key Themes in Qualitative Research: Continues and Changes. New York: Altamira Press. 
Barnier, M., 2008. Qui va nourrir le monde? Pour une nouvelle révolution agricole. Paris: Acropole Belfond Press.

Baron, J., 2008. Thinking and deciding. Cambridge: Cambridge University Press.

Barrena, R. and Sanchez, M., 2009. Differences in Consumer Abstraction Levels as a Function of Risk Perception. Journal of Agricultural Economics, 61(1), pp.34-59.

Blue Skies, 2012. The JEE Report 2010-2011 - Our blue print for a sustainable business. Pitsford; Blue Skies Holdings. [online] Available at: <http://www.blueskies.com/ jee.pdf.> [Accessed 5.09.2017].

Bouquet, P., 2012. Social media marketing in the American and French wine industry in 2012. Social Media Marketing. [online] Available at: <http://www. slideshare.net/ pierrickbouquet/social-media-marketing-in-the-american-and-french-wine-industry-in2012> [Accessed 20.08.2017].

Bradbury, H. and Reason, P., 2001. Conclusion: Broadening the Bandwidth of Validity: Issues and Choice-Points for Improving the Quality of Action Research. In: P. Reason and H. Bradbury, ed. 2001. Handbook of Action Research: Participative Inquiry and Practice. Thousand Oaks: Sage Publications. pp.447-455.

Brătucu, G. and Brătucu, T.O., 2016. Metode calitative utilizate în cercetarea pieţei. Revista Management\&Marketing, 1, pp.47-55.

Brutland Comission, 1987. Report of the World Commission on Environment and Development: Our Common Future. [online] Available at: <http://www.undocuments.net/our-common-future.pdf > [Accessed 19.09.2017].

Cătoiu, I., Bălan, C., Orzan, Gh., Vegheș, C., Dănețiu, T. and Vrânceanu, D.M., 2002. Cercetări de marketing. București: Uranus.

Cho, C., 2016. Organized hypocrisy, organizational façades, and sustainability reporting. Accounting, Organizations and Society, 40, pp.78-94.

Cho, J. and Tent, A., 2006. Validity in qualitative research revisited. Qualitative Research, Sage Journals, 6(3), pp.319-340.

Cohen, E., d'Hauteville, F. and Sirieix, L., 2009. A cross-cultural comparison of choice criteria for wine in restaurants. International Journal of Wine Business Research, 21, pp.50-63.

Council Directive CEE/79/112 of 18 December 1978 on the approximation of the laws of the Member States relating to the labelling, presentation and advertising of foodstuffs for sale to the ultimate consumer. [online] Available at: <http://www.wipo.int/ wipolex/en/details.jsp?id=1436> [Accessed 17.09.2017].

Council Directive CEE/84/450 of 10 September 1984 concerning misleading and comparative advertising. [online] Available at: <http:/eur-lex.europa.eu/legalcontent/RO/ALL/?uri=CELEX\% 3A32006 L0114> [Accessed 17.09.2017].

Creswell, J. and Miller, D., 2000. Determining Validity in Qualitative Inquiry. Theory Into Practice, 39(3), pp.124-130.

Csávossy, G, 2017. Millesime - revista de cultură şi civilizație a vinului. [online] Available at: <http://millesime.ro/gheorghe-csavossy> [Accessed 19 September 2017].

Del Chiappa, G., Grappi, S. and Romani, S., 2016. Attitudes toward responsible tourism and behavioral change to practice it: a demand-side perspective in the context of Italy. Journal of Quality Assurance in Hospitality \& Tourism, 17(2), pp.191-208. 
Diaconescu, M., 2005. Marketing agroalimentar. București: University Press.

Dressler, M., 2016. Prosumers in the wine market: An explorative study. Wine Economics and Policy, 5, pp.24-32.

European Commission, 2012. Consolidated Version of the Treaty on European Union and the Treaty on the Functioning of the European Union - 2012/C 326/01. [online] Available at: <http://eur-lex.europa.eu/legal-content/RO/TXT/?uri=celex\%3A12012E $\% 2 F T X T>$ [Accessed 19.09.2017].

European Commission, 2013. Common Agricultural Policy. [online] Available at: <https://ec.europa.eu/ [Accessed 04.12.2017].

European Union Intellectual Property Office, 2017. Infringement of protected geographical indications for wine, spirts, agricultural, products and foodstuffs in the European Union. [online] Available at: <https://euipo.europa.eu/tunnel-web/secure/ webdav/guest/document_library/ observatory/documents/Geographical_indications_report/geographical_indications_rep ort_en.pdf $>$ [Accessed 17.09.2017].

Evseev, I., 1999. Enciclopedia simbolurilor religioase și arhetipuri culturale. Timișoara: Amarcord Press.

Fine, M., Weis, L., Weseen, S. and Wong, L., 2000. For Whom: Qualitative Research, Representations, and Social Responsibilities/ In: N.K. Denzin and Y.S. Lincoln, ed. 2000. Handbook of Qualitative Research, 2nd Edition. London: Sage Publications. pp.107-131.

Gârdan, D.A., Geangu, I.P. and Roșu, A.M., 2011. Marketing research regarding mobile marketing implications for romanian services consumers. Proceedings of the 6th International Conference on Business Excellence. Braşov: Editura Universităţii Transilvania din Braşov. pp.229-232.

Gereffi, G., Humphrey, J. and Sturgeon, T., 2005. The governance of global value chains. Review of International Political Economy, 12(1), pp.78-104.

Golafshani, N., 2003. Understanding Reliability and Validity in Qualitative Research. The Qualitative Report, 8(4), pp.597-606.

Goodman, S., 2009. An international comparison of retail consumer wine choice. International Journal of Wine Business Research, 21, pp.41-49.

Halstead, L., 2013. Consumer trends in the wine industry for 2013. Wine and Viticulture Journal, 1, pp.72-73.

Hollebeek, L.D., 2011. Exploring customer brand engagement: Definition and themes. Journal of Strategic Marketing, 19(7), pp.555-573.

Hollebeek, L.D., Jaeger, S.R., Brodie, R.J. and Balemi, A., 2007. The influence of involvement on purchase intention for new world wine. Food Quality and Preference 18, pp.1033-1049.

Iancu, P., 2013. Wine - a phenomenon of culture and spirituality.Hârlău: Studis Press.

Law no. 164/2015 of vine and wine in the system of the common organization of the wine market. [online] Available at: <https://www.onvpv.ro/sites/default/files/20150722 legea_viei_si_vinului_164_2015.pdf>[Accessed 17.09.2017]. 
Lindsey, M., Higgins, L.M., McGarryWolf, M. and Wolf, J., 2014. Technological change in the wine market? The role of QR codes and wine apps in consumer wine purchases. Wine Economics and Policy, 3, pp.19-27.

Lipson, M., 2007. Peacekeeping: Organized Hypocrisy?. European Journal of International Relations, (13)1, pp.5-34.

Lockshin, L., and Hall, J., 2003. Consumer purchasing behaviour for wine: what we know and where we are going. Proceedings of the International Wine Marketing Colloquium. Adelaide: University of South Australia.

Malterud, K., Siersma, V.D. and Guassora, A.D., 2016. Sample Size in Qualitative Interview Studies: Guided by Information Power. Qualitative Health Research, 26(13) pp.1753-1760.

Marinelli, N., Fabbrizzi S., Alampi Sottini, V., Sacchelli, S., Bernetti, I. and Menghini, S., 2014. Generation Y, wine and alcohol. A semantic differential approach to consumption analysis in Tuscany. Appetite, 75, pp.117-127.

Maric, R., Grgic, T., Matijasevic, M. and Lovrek, I., 2015. Online Charging Based on Machine Context for M2M Communication in LTE. In: M. Aguayo-Torres., G. Gómez, J. Poncela (eds). Wired/Wireless Internet Communications - Lecture Notes in Computer Science, 9071, pp.18-31.

McDonald, J., 2016. Factors influencing premiums on local wines: an exploratory assessment of Kansas wine. [online] Available at: <http://krex.k-state.edu/ dspace/handle /2097/32727> [Accessed 06.12.2017].

McIntyre, E., Ovington, L.A., Saliba, A.J. and Moran, C.C., 2015. Qualitative study of alcohol consumers who choose to avoid wine. Australian Journal of Grape and Wine Research, no.22, pp.182-189.

Moody, R., Kireeva, I. and Butucel, I., 2010. Legislația și politica agrară și alimentară. Aproximarea la standardele UE în Republica Moldova. Chișinău: IBF International.

National Office of Vine and Wine Products, 2017. Wine growers in Romania, by regions, by size in 2016. [online] Available at: <https://www.onvpv.ro/> [Accessed 15.09.2017].

Neven, D., 2015. Développer des chaînes de valeur durables. Principes directeurs. Roma: Organisation des Nations Unies pour l'Alimentation et l'Agriculture.

Orthodox Bible, 2017. Songs of Songs. [online] Available at: <https://www. bibliaortodoxa.ro/> [Accessed 15.09.2017].

Perkins, R. and Neumayer, E., 2010. The organized hypocrisy of ethical foreign policy: Human rights, democracy and Western arms sales. Geoforum, 41(2), pp.247-256.

Plous, S., 1993. The Psychology of Judgment and Decision Making. New York: McGrawHill Education.

Pomarici, E., Vecchio, R. and Mariani, A., 2015. Wineries' perception of sustainability costs and benefits: an exploratory study in California. Sustainability,7, pp.16164-16174.

Regulation (EC) no. 178/2002 of the European Parliament and of the Council of 28 January 2002 laying down the general principles and requirements of food law, establishing the European Food Safety Authority and laying down procedures in matters of food safety. [online] Available at: <http://www.ansvsa.ro/download/ legislatie/zoonoze/Regulament-178_2002-cerinte-legisl-alimentara-instituire-a-AESAsi-stab-a-procedurilor-in-domeniul-sigurantei-prod-alimentare_RO.pdf $>$ [Accessed 15.07.2017]. 
Regulation (EC) no. 234/79 of the Council on the procedure for adjusting the Common Customs Tariff nomenclature used for agricultural products. [online] Available at: <http://eur-lex.europa.eu/legal-content/RO/TXT/?uri=CELEX\%3A31989R3209> [Accessed on 18.07.2017].

Regulation (EC) no. 852/2004 of the European Parliament and of the Council of 29 April 2004 on the hygiene of foodstuffs. [online] Available at: <http://eur-lex.europa.eu/ LexUriServ/LexUriServ.do?uri=CONSLEG:2004R0852:20090420:RO:PDF> [Accessed 15.07.2017].

Regulation (EC) no. 853/2004 of the European Parliament and of the Council of 29 April 2004 laying down specific hygiene rules for food of animal origin. [online] Available at: $\quad<$ http://www.ansvsa.ro/download/legislatie/leg_igiena/Regulament-853_2004stabilire-a-unor-normespecifice-de-igiena-care-se-aplica-alimentelor-de-origineanimala-forma-consolidata_10.pdf $>$ [Accessed 15.07.2017].

Regulation (EC) no. 854/2004 of the European Parliament and of the Council of 29 April 2004 laying down specific rules for the organization of official controls on products of animal origin intended for human consumption. [online] Available at: $<$ http://www.ansvsa.ro/download/legislatie/leg_igiena/Regulament-854_2004-normeorganizare-a-controalelor-oficiale-priv-produsele-de-origine-animala-destinateconsumului-uman_10078ro.pdf $>$ [Accessed on 15.07.2017].

Regulation (EC) no. 882/2004 of the European Parliament and of the Council of 29 April 2004 on official controls performed to ensure the verification of compliance with feed and food law, animal health and animal welfare rules. [online] Available at: $<$ http://eur-lex.europa.eu/legal-content/RO/TXT/PDF/?uri=CELEX:32004R0882\& from $=\mathrm{RO}>$ [Accessed on 15.07.2017].

Regulation (EC) no. 922/72 of the Council of 2 May 1972 laying down general rules for the granting of aid for silkworm for the 1972/73 growing year laying down general rules for the granting of aid for worms. [online] Available at: <http://eurlex.europa.eu/eli/reg/1972/922/1974-04-01/ron/pdf > [Accessed 18.07.2017].

Regulation (EC) no. 1037/2001 of the Council of 22 May 2001 authorizing the offer and delivery for direct human consumption of certain imported wines which may have undergone oenological processes not provided for in Regulation (EC) No 1493/1999. [online] Available at: <http://eur-lex.europa.eu/legal-content/RO/ALL/?uri=CELEX\%3 A32001R1037> [Accessed 18.07.2017].

Regulation (EC) no. 1169/2011 of the European Parliament and of the Council of 25 October 2011 on the provision of food information to consumers. [online] Available at: <http://eur-lex.europa.eu/legal-content/en/TXT/?uri=CELEX \%3A3 2011R1169> [Accessed 15.07.2017].

Regulation (EC) no. 1234/2007 of the Council of 22 October 2007 establishing a common organisation of agricultural markets and on specific provisions for certain agricultural products. [online] Available at: <http://eur-lex.europa.eu/legal-content/RO/ALL/?uri= celex:32007R1234> [Accessed 18.07.2017].

Regulation (EC) no. 1305/2013 of the European Parliament and of the Council of 17 December 2013 on support for rural development by the European Agricultural Fund for Rural Development (EAFRD. [online] Available at: $<$ http://eur-lex.europa.eu /legal-content/en/ALL/?uri=CELEX\%3A32013R1305> [Accessed 16.07.2017]. 
Regulation (EC) no. 1308/2013 of the European Parliament and of the Council of 17 December 2013 establishing a common organisation of the markets in agricultural products and repealing Council Regulations (EEC) No 922/72, (EEC) no. 234/79, (EC) no. 1037/2001 and (EC) no. 1234/2007. [online] Available at: <https://www.onvpv.ro/ sites/default/files/rce_1308_2013_scmo.pdf > [Accessed 18.07.2017].

Regulation (EC) no. 1830/2003 of the European Parliament and of the Council of 22 September 2003 concerning the traceability and labeling of genetically modified organisms and the traceability of food and feed products produced from genetically modified organisms. [online] Available at: <http://eur-lex.europa.eu/legal-content/RO/ ALL/?uri=celex:32003R1830 > [Accessed 15.07.2017].

Regulation (EC) no. 2073/2005 of the European Commission of 15 November 2005 on microbiological criteria for foodstuffs. [online] Available at: <http://www.ansvsa.ro/ download/legislatie/zoonoze/ Regulament-2073_2005-criteriile-microbiologice-pentruprodusele-alimentare-forma-consolidata_RO.pdf $>$ [Accessed 15.07.2017].

Resolution OIV-VITI 422/2011 - Guidelines for sustainable viticulture adapred to table grapes and raisins production, storage, processing and packaging of products. [online] Available at: <http://www.oiv.int/public/medias/395/viti-2011-1-en.pdf> [Accessed 17.06.2017].

Resolution UN 39/248/1985 Guiding principles for consumer protection. [online] Available at: <http://www.un.org/documents/ga/res/39/a39r248.htm> [Accessed 17.06.2017].

Romanian Government Decision no. 106/2002 on the labeling of foodstuffs. [online] Available at: <http://www.anpc.gov.ro/anpcftp/anpc_junior/hg106_2002_cu_ modificari.pdf $>$ [Accessed 21.09.2017].

Romanian Ministry of Agriculture and Rural Development, 2013. Romanian Ministry of Agriculture and Rural Development, 2013. [online] Available at: <http://www.madr.ro/agricultura-ecologica.html> [Accessed 06.12.2017].

Santeramo, F.G., 2015. Promoting the international demand for agritourism - empirical evidence from a dynamic panel data model. Tourism Economics, 21(4), pp.907-916.

Santeramo, F.G., Seccia, A. and Nardone, G., 2017. The synergies of the Italian wine and tourism sectors. Wine Economics and Policy 6, pp.71-74.

Silverman, D., 2013. Doing Qualitative Research. London: Sage Publications Ltd.

Thach, L., 2009. Wine 2.0 - the next phase of wine marketing? ExploringU.S. winery adoption of wine 2.0 components. Journal of Wine Research, 20(2), pp.143-157.

Tian-Que, L., 2012. Perceived Risk in Marketing Strategy. In: M. Zhu, ed. 2012. Business, Economics, Financial Sciences, and Management. Advances in Intelligent and Soft Computing. Berlin: Springer. pp.175-178.

Vin \& Société, 2017. Consommation responsable. [online] Available at: <http://www. vinetsociete.fr/s-engager/consommation-responsable > [Accessed 19.09.2017].

Vivek, S.D., Beaty, S.E. and Morgan, R.M., 2012. Customer engagement: exploring customer relationships beyond purchase. Journal of Marketing. Theory and Practice. 20 (2), pp.122-146.

Winkler, K.J. and Nicholas, K.A., 2016. More than wine: cultural ecosystem services in vineyard landscapes in Englandand California. Ecological Economics, 124, pp.86-98. 